\title{
Study of clarification process of sugar cane juice for consumption
}

\author{
Desenvolvimento de processo de clarificação de caldo de cana para consumo
}

\author{
Patricia PRATI ${ }^{1 *}$, Roberto Hermínio MORETTI ${ }^{2}$
}

\begin{abstract}
Sugar cane juice or garapa darkens quickly after extraction due to the oxidation of some of its constituents harming its commercialization thus requiring rapid consumption. The objective of this study was to develop a mild process for sugar cane clarification, obtaining a cloudy, greenish-yellow beverage. The following parameters were combined to aiming at this objective: heat treatment at $65^{\circ} \mathrm{C} / 50 \mathrm{minutes}$; $\mathrm{pH}$ change (to 7.0, 7.5, and 8.0); addition of flocculant (0,30, and $60 \mathrm{ppm}$ Aluminum polychloride or APC - "Panclar P-1010"), and clarifier aid (0, 2 , or 4 ppm of positively charged polyelectrolyte - "Magnafloc LT-27"). The decantation time was 45 minutes and the supernatant liquid was removed with a vacuum pump. The treatments were defined using the Response Surface Methodology and were submitted to physicochemical analysis for turbidity $(\%)$, total polysaccharide content $\left(\mu \mathrm{g} . \mathrm{mL}^{-1}\right)$, dextran content $\left(\mu \mathrm{g} . \mathrm{mL}^{-1}\right)$, and sensory analysis (acceptance test) for the attributes of color, appearance, and turbidity. It was concluded that the addition of $60 \mathrm{ppm} \mathrm{APC,} \mathrm{pH} 8$, and 0 ppm polyelectrolyte represented the best treatment to obtain a low polysaccharide content, $90 \%$ turbidity, and high scores for color, appearance, and turbidity. The beverage was sensorially well accepted by consumers.
\end{abstract}

Keywords: sugar cane; liquids - clarification; sensory evaluation.

\section{Resumo}

A garapa ou caldo de cana, após sua extração, escurece em razão da oxidação de seus constituintes. Este fato prejudica a comercialização da bebida que então deve ser consumida rapidamente. O presente trabalho teve como objetivo desenvolver um processo brando de clarificação do caldo de cana de forma a obter uma garapa turva e de coloração amarelo-esverdeada. Para alcançar este objetivo, associaram-se: aquecimento a $65^{\circ} \mathrm{C} / 50$ minutos; mudança de $\mathrm{pH}$ do meio (valores de $\mathrm{pH} 7,0 ; 7,5 ;$ e 8,0); adição de floculante $(0,30$ e 60 ppm de Policloreto de Alumínio ou PAC - "Panclar P-1010"); e auxiliar de clarificação (0, 2 e 4 ppm de polieletrólito negativamente carregado - "Magnafloc LT-27”). O tempo de decantação foi de 45 minutos e o líquido sobrenadante foi removido com o auxílio de bomba de vácuo. Os tratamentos foram definidos através de Planejamento Experimental Fatorial e submetidos a análises físico-químicas de turbidez (\%), teor de polissacarídeos totais ( $\mu$ g.mL $\left.{ }^{-1}\right)$, teor de dextrana ( $\mu \mathrm{g} \cdot \mathrm{mL}^{-1}$ ), e análise sensorial (Teste de Aceitação) para os atributos cor, aparência e turbidez. Concluiu-se que, o melhor tratamento (altas notas para os atributos cor, aparência e turbidez, teor mediano de polissacarídeos e aproximadamente $90 \%$ de turbidez) foi aquele no qual se utilizaram $60 \mathrm{ppm}$ de PAC, $\mathrm{pH}$ 8,0 e $0 \mathrm{ppm}$ de polieletrólito. Sensorialmente a bebida foi bem aceita pelos consumidores. Palavras-chave: cana-de-açúcar; clarificação do líquido; análise sensorial.

\section{Introduction}

If stored, sugar cane juice must be clarified since it darkens minutes after extraction due to the oxidation of some of its components (especially chlorophyll and polyphenolic compounds), which can negatively affect its consumption.

According to Leme Junior and Borges (1965), clarification must be carried out soon after grinding to avoid enzymatic action. Clarification by simple decanting was not an option since the product consists of a complex colloidal system in which the colloids present different isoelectric points.

The clarification of sugar cane juice occurs by coagulation, flocculation, and precipitation of the colloids and pigmented substances, which are later eliminated by decanting and filtration, i.e., an insoluble precipitate which absorbs and drags such compounds from the juice is formed. Flocculation can be carried out by changing the $\mathrm{pH}$, using chemical reagents, or through heating (KOBLITZ; MORETTI, 1999; STUPIELLO, 1987).
In Brazil, two methods for clarifying sugar cane juice predominate: simple defecation with lime and heating to obtain the crude sugar, and sulf-defecation, in which sulfur dioxide is added before treating with lime and heating to obtain white crystal sugar. Some mills use phosphate as well obtaining even lighter juices with greater elimination of the colloids and quicker decanting (KOBLITZ, 1998).

Of all coagulants used for water treatment, the most commonly used in Brazil is the aluminum sulfate, a more soluble product, easy to store and transport and readily available in the market (KOBLITZ, 1998).

Currently, water treatment plants in the State of São Paulo, Brazil, are testing a new coagulant developed in Japan. It is known as Aluminum Polychloride (APC) and shows several advantages over the normally used coagulants: promotes flocculation at any $\mathrm{pH}$; it is more efficient in colloid removal than

Recebido para publicação em 30/10/2008

Aceito para publicação em 25/9/2009 (003842)

${ }^{1}$ Instituto de Tecnologia de Alimentos, Av. Esplanada de Cristo, n. 325, Novo Horizonte, CEP 13520-000, São Pedro - SP, Brasil, E-mail: pprati00@yahoo.com

${ }^{2}$ Faculdade de Engenharia de Alimentos, Universidade Estadual de Campinas - UNICAMP, E-mail: moretti@fea.unicamp.br

${ }^{*}$ A quem a correspondência deve ser enviada 
the aluminum sulfate reducing reagent expense; and creates less aluminum residue in the final product (KOBLITZ, 1998). The manufacturer recommends a maximum dose of $1000 \mathrm{ppm}$.

For coagulation to occur, the medium must be alkaline and produced by the medium or by the presence of alkalinizing agents such as calcium oxide (quick lime), calcium hydroxide (slaked lime), sodium hydroxide, or sodium carbonate. When added to juice, such reagents modify the $\mathrm{pH}$, and together with the effect of temperature, form precipitates which remove impurities (KOBLITZ, 1998).

It is difficult to establish an optimum $\mathrm{pH}$ for the clarification process, but it is known that the simple application of lime (freshly made) up to a $\mathrm{pH}$ range between 7.5 and 8.5 can produce satisfactory clarification (SOUZA, 1988).

Currently, clarification/flocculation aids are added to increase the efficiency and yield clarification, i.e., the products added to the juice can significantly contribute to the elimination of impurities since their main objective is to make the floccules denser and aid decanting. These substances include clay, activated silica, phosphoric acid, bentonite, polyelectrolytes, and magnesium oxide (DELGADO, 1975, KOBLITZ; MORETTI, 1999; SOUZA, 1988).

Polyelectrolytes are high molecular weight synthetic organic compounds, which are soluble in water. They have been widely used as clarifying aids contributing to improve flocculation and increase the efficiency of decanting impurities into the juice. They promote the agglutination of previously coagulated particles contributing to improved flocculation and an increase in the efficiency of decanting the impurities into the juice. They promote the agglutination of previously coagulated particles, floccules formed covering, and imprisoning other crude impurities. Cationic polyelectrolytes are more effective than anionic ones since the majority of the colloidal particles of the juice have a negative charge (DELGADO; CESAR, 1989).

The ideal amount of polyelectrolyte to be added depends on its quality and on the characteristics of the available polymer. In general, the dose for treating the juice has varied between 1 and $3 \mathrm{ppm}$ although the American legislation allows a limit of $5 \mathrm{ppm}$. The addition of larger amounts of this reagent can provoke the opposite effect and thus instead of provoking particle attraction, it actually stabilizes the colloid and make flocculation more difficult (COPERSUCAR, 1994; PAYNE, 1989)

The subsequent heating of the juice from $90{ }^{\circ} \mathrm{C}$ to approximately $105{ }^{\circ} \mathrm{C}$ aimed at accelerating and favoring coagulation and flocculation of the colloids and non-sugar proteins emulsifying fatty matter and waxes, i.e., accelerating the chemical process and increasing decanting efficiency.

Decanting is the last step, which aims at increasing the life of the filters, but is not indispensable in the colloid removal process. Filtration is a fundamental step in the removal not only of the colloids but also of suspended impurities, and it should be carried out with the aid of diatomaceous earth. In general, such procedure is sufficient to perfectly clarify syrups (KOBLITZ; MORETTI, 1999).
Koblitz and Moretti (1999) studied the efficiency of different concentrations of aluminum polychloride (APC - "Panclar P-1010") and negatively charged polyelectrolyte (Magnafloc LT-27) in the clarification of sugar syrups at different $\mathrm{pH}$ values $(7,9$, and 11). According to this research, the best results in terms of the removal of colored colloids and lack of floccules after processing were obtained with $50 \mathrm{ppm}$ of APC and $2 \mathrm{ppm}$ polyelectrolyte at $\mathrm{pH}$ values of 9 and 11 . According to the manufacturer, the Magnafloc LT-27 flocculant is an ultrahigh weight anionic polyacrylamide supplied as a free-flowing granular powder.

As previously stated, the objective of clarifying sugar cane juice for human consumption is that of obtaining a cloudy solution and not a clear one, but a yellow colored juice, different from the dark green original juice. To attain this objective, the chlorophyll must be degraded and this is achieved by acidifying the product, and the greater the amount of acid added, the more the product loses the green color thus acquiring a yellowish green tone.

This change is based on the fact that the interaction between the chlorophyll and the acids present in the medium results in the loss of the chlorophyll's magnesium ion, which is then substituted by one of the protons supplied by the acids. In the case of sugar cane juice, this substitution results in the formation of a yellowish-green color, whereas regarding fruits and vegetables there is a color change from green to olive green (IADEROZA; DRAETTA, 1991).

The objective of this research was the development of a mild clarification process for sugar cane juice associating heating with changes in the medium $\mathrm{pH}$ and the addition of flocculants and clarification aids, aluminum polychloride and negatively charged polyelectrolyte respectively.

\section{Materials and methods}

Before extraction, the peel of the sugar canes (variety RB72454) was removed, and both the canes and the mill sanitized. The extracted juice was immediately submitted to pre-conditioning, decanting, and acidification as described below.

The process consisted of adjusting the $\mathrm{pH}$ to between 7 and 8, a range shown to be efficient for clarification according to Koblitz and Moretti (1999), and adding chemical products (coagulating agent and clarification) associated with heating.

Since the $\mathrm{pH}$ was raised in order to effect clarification, it was necessary to acidify again to $\mathrm{pH}$ values equal or below $\mathrm{pH} 4.0$ to inhibit the growth of pathogenic microorganisms. This procedure also contributed to the clarification of the juice. The product was acidified with $10 \%$ citric acid.

The clarification aids tested were aluminum polychloride (APC - "Panclar P-1010") and a negatively charged polyelectrolyte ("Magnofloc), testing 3 different concentrations of each: 0, 30, and $60 \mathrm{ppm}$ of APC and 0,2 , and $4 \mathrm{ppm}$ of the polyelectrolyte. The $\mathrm{pH}$ values tested were 7.0, 7.5, and 8.0.

The processing steps were as follows:

- Extraction of juice (mill); 
- Pre-conditioning for clarification: heating $\left(65^{\circ} \mathrm{C} /\right.$ 50 minutes): alkalinization $(1,25 \% \mathrm{Ca}(\mathrm{OH})$, to the desired $\mathrm{pH}$ ); addition of coagulating agents (polyelectrolyte + APC);

- Decanting for 40 minutes;

- Separation of the supernatant with a vacuum pump;

- Acidification with $10 \%$ citric acid; and

- Analyses.

The values of time-temperature $\left(65^{\circ} \mathrm{C} / 50\right.$ minutes $)$ of the heating during the clarification process and the decantation's time (40 minutes) were established through preliminary assays and were considered the best parameters to promote an adequate flocculation and separation of sugar cane juice's constituents.

The following analyses were carried out to evaluate the efficiency of clarification:

- Measurement of turbidity in a color spectrophotometer, model COLORQUEST II from Hunterlab, with CIELAB D65/10 system;

- Determination of total polysaccharide content using the technique described by Koblitz (1998) using a semi-permeable dialysis membrane to separate the polysaccharides followed by their quantification the anthrone solution according to Dreywood (1946);

- The dextran content was determined by the phenolsulphuric method described by Roberts (1982). The statistical analysis was performed using the Response Surface Methodology (BARROS NETO; SCARMINIO; BRUNS, 1995) with a complete $2^{3}$ factorial design $(\mathrm{p}<0.05)$ with three independent variables (APC, polyelectrolyte, $\mathrm{pH}$ ) and three dependent variables (responses - turbidity and total polysaccharide and dextran contents), as shown in Table 1.

- Sensory analysis: the acceptance test was applied using a 9-point non-structured hedonic scale (affective method) evaluating color, turbidity, and global appearance in order to determine consumer acceptance with respect to the visual sensory attributes (STONE; SIDEL, 1993). The panel consisted of 30 non-trained judges and the samples (11 trials) were coded according to the instructions established in the literature. The results were also analyzed through the Response Surface Methodology $(\mathrm{p}<0.30)$. The best treatment was chosen based on a block analysis of the physicochemical determinations and the sensory acceptance test. In order to evaluate the product's acceptance by the consumers, the chosen treatment was submitted to another acceptance test for flavor, taste, and global impression, as related before, through a sensorial test of purchase's intention with scores varying form 5 ("certainly would buy") to 1 ("certainly wouldn't buy) (MEILGAARD; CIVILLE; CARR, 1987).

- The color of each product was determined in a colorimetercolor spectrophotometer, model color QUEST II from Hunterlab.

\section{Results and discussion}

\subsection{Physicochemical analysis}

Table 2 shows the results of the determinations of dextran, total polysaccharides, and turbidity.

With respect to the dextran content, the response surface showed that none of the variables (APC, $\mathrm{pH}$ and polyelectrolyte) had a significant effect on the response at $\mathrm{p}<0.05$ within the concentration ranges tested. Thus, there is no predictive model for this analysis.

Table 2. Results of the turbidity analysis and determination of total polysaccharide and dextran contents.

\begin{tabular}{cccc}
\hline $\begin{array}{c}\text { Treatment } \\
\text { (assay) }\end{array}$ & $\begin{array}{c}\text { Dextran } \\
\left(\mu \mathrm{gg} \cdot \mathrm{mL}^{-1}\right)\end{array}$ & $\begin{array}{c}\text { Polysaccharide total } \\
\left(\mu \mathrm{g} \cdot \mathrm{mL}^{-1}\right)\end{array}$ & $\begin{array}{c}\text { Turbidity } \\
(\%)\end{array}$ \\
\hline 1 & 7,58 & 22,96 & 93,33 \\
2 & 2,49 & 26,21 & 91,95 \\
3 & 10,84 & 79,51 & 76,94 \\
4 & 15,75 & 29,22 & 92,39 \\
5 & 8,47 & 64,41 & 91,55 \\
6 & 14,02 & 27,36 & 93,22 \\
7 & 6,18 & 66,18 & 53,09 \\
8 & 13,09 & 32,46 & 70,34 \\
9 & 11,46 & 35,34 & 93,18 \\
10 & 13,47 & 67,26 & 91,63 \\
11 & 8,59 & 48,07 & 91,70 \\
Natural sugar cane juice & 21,15 & 54,4 & 88,21 \\
\hline
\end{tabular}

Table 1. Variable parameters in the assays (independent variables).

\begin{tabular}{|c|c|c|c|c|c|c|}
\hline \multirow{2}{*}{$\begin{array}{c}\text { Assays } \\
\text { (treatment) }\end{array}$} & \multicolumn{2}{|c|}{$\mathrm{APC}(\mathrm{ppm})$} & \multicolumn{2}{|c|}{$\mathrm{pH}$} & \multicolumn{2}{|c|}{ Polyelectrolyte (ppm) } \\
\hline & Codified & Decodified & Codified & Decodified & Codified & Decodified \\
\hline 1 & -1 & 0 & -1 & 7,0 & -1 & 0 \\
\hline 2 & 1 & 60 & -1 & 7,0 & -1 & 0 \\
\hline 3 & -1 & 0 & 1 & 8,0 & -1 & 0 \\
\hline 4 & 1 & 60 & 1 & 8,0 & -1 & 0 \\
\hline 5 & -1 & 0 & -1 & 7,0 & 1 & 4 \\
\hline 6 & 1 & 60 & -1 & 7,0 & 1 & 4 \\
\hline 7 & -1 & 0 & 1 & 8,0 & 1 & 4 \\
\hline 8 & 1 & 60 & 1 & 8,0 & 1 & 4 \\
\hline 9 & 0 & 30 & 0 & 7,5 & 0 & 2 \\
\hline 10 & 0 & 30 & 0 & 7,5 & 0 & 2 \\
\hline 11 & 0 & 30 & 0 & 7,5 & 0 & 2 \\
\hline
\end{tabular}


When the model explained only $45 \%$ of the results' variation, which represents much lower than that the $85 \%$ recommended, the response surfaces wer not generated

Analyzing the effects and the coefficients of regression of the factors APC, $\mathrm{pH}$, and polyelectrolyte (linear regression and the interactions between them) for the total polysaccharide contents, it was concluded that the effect of APC was the only significant effect with respect to the response at the $95 \%$ level of confidence (Table 3).

By eliminating the non-significant factors, the significance of the regression and the lack of adjustment at $\mathrm{p}<0.05$ were verified using the Ftest of the analysis of variance (ANOVA). The adjusted model was considered predictive since it presented a significant regression at the $95 \%$ level of confidence $\left(\mathrm{F}_{\text {calc. regression }}=7.95>\mathrm{F}_{\text {tab; } 0.05 ; 1 ; 9}=5.12\right)$ and a non-significant lack of adjustment at the same level $\left(\mathrm{F}_{\text {calc.lack of adjust }}=1,21<\mathrm{F}_{\text {tab;0.05; ; ; }}=3.29\right)$ despite the regression coefficient $\left(\mathrm{R}^{2}=0.45\right)$ being below 0.85 .

Analyzing the effects and regression coefficients of the factors APC, $\mathrm{pH}$, and polyelectrolyte (linear regression and the interactions between them) for turbidity, it was concluded that only the effect of the interaction $\left[\mathrm{APC}^{\star}\right.$ polyelectrolyte] was not significant for the response at the $95 \%$ level of significance (Table 4).

By eliminating the non-significant factor, the significance of the regression and the lack of adjustment at $\mathrm{p}<0.05$ were verified using the F-test of the analysis of variance (ANOVA). The adjusted model was considered predictive since it presented a significant regression at the $95 \%$ level of confidence $\left(\mathrm{F}_{\text {calc. regression }}=7,94>\mathrm{F}_{\text {tab; } 0.05 ; 5 ; 5}=5.05\right)$, a non-significant lack of adjustment at the same level $\left(\mathrm{F}_{\text {calc.lack of adjust }}=1.65<\mathrm{F}_{\text {tab; } 0.05 ; 3 ; 5}=3.29\right)$, and

Table 3. Estimated effect, statistical significance, and coefficient of regression of the factors for the total polysaccharide content $\left(\mathrm{R}^{2}=0.45\right)$.

\begin{tabular}{lccc}
\hline \multicolumn{1}{c}{ Factors } & $\begin{array}{c}\text { Estimated } \\
\text { effect }\end{array}$ & $\begin{array}{c}\text { Statistical } \\
\text { significance }(\mathrm{p})\end{array}$ & $\begin{array}{c}\text { Regression } \\
\text { coefficient }\end{array}$ \\
\hline General mean & 42,44727 & 0,002744 & 42,44727 \\
$(1)$ APC & $-29,4525$ & 0,030069 & $-14,7263$ \\
$(2)$ pH & 16,6075 & 0,086379 & 8,30375 \\
$(3)$ polyelectrolyte & 8,1275 & 0,260141 & 4,06375 \\
$1 * 2$ & $-12,5525$ & 0,138264 & $-6,27625$ \\
$1 * 3$ & $-5,9325$ & 0,374008 & $-2,96625$ \\
$2 * 3$ & $-13,1725$ & 0,127884 & $-6,58625$ \\
\hline
\end{tabular}

Table 4. Estimated effect, statistical significance, and regression coefficient of the factors for turbidity $\left(\mathrm{R}^{2}=0.89\right)$.

\begin{tabular}{lccc}
\hline \multicolumn{1}{c}{ Factors } & $\begin{array}{c}\text { Estimated } \\
\text { effect }\end{array}$ & $\begin{array}{c}\text { Statistical } \\
\text { significance }(\mathrm{p})\end{array}$ & $\begin{array}{c}\text { Regression } \\
\text { coefficient }\end{array}$ \\
\hline General mean & 85,39273 & $9,55 \mathrm{E}-06$ & 85,39273 \\
$(1)$ APC & 8,2475 & 0,005586 & 4,12375 \\
$(2)$ pH & $-19,3225$ & 0,001025 & $-9,66125$ \\
$(3)$ polyelectrolyte & $-11,6025$ & 0,002834 & $-5,80125$ \\
$1^{*} 2$ & 8,1025 & 0,005786 & 4,05125 \\
$1^{* 3}$ & 1,2125 & 0,189223 & 0,60625 \\
$2^{* 3}$ & $-11,3475$ & 0,002962 & $-5,67375$ \\
\hline
\end{tabular}

a regression coefficient $\left(\mathrm{R}^{2}=0.89\right)$ greater than 0.85 . Figures 1 and 2 illustrate the effects of the significant interactions with respect to the response "turbidity".

Figure 1 shows the major effect of the $\mathrm{pH}^{\prime}$ s increase on the decrease in the turbidity's values.

Nevertheless, Figure 2 suggests that the turbidity values occurred at higher chosen values of $\mathrm{pH}$ and polyelectrolyte, i.e., the highest values these two parameters at the same time promote major flocculation resulting in a less cloudy product.

\subsection{Sensory analysis}

Table 5 shows the scores awarded to the different treatments by the judges.

Annalyzing the effects and regression coefficients of the factors APC, $\mathrm{pH}$, and polyelectolyte (linear regression and the interactions between them) for the attribute of turbidity, it was possible to conclude that only the interactions [APC ${ }^{\star}$ polyelectrolyte] and $\left[\mathrm{pH}^{\star}\right.$ polyelectrolyte] showed significant effects on the response at a level of $75 \%$ of significance (Table 6).

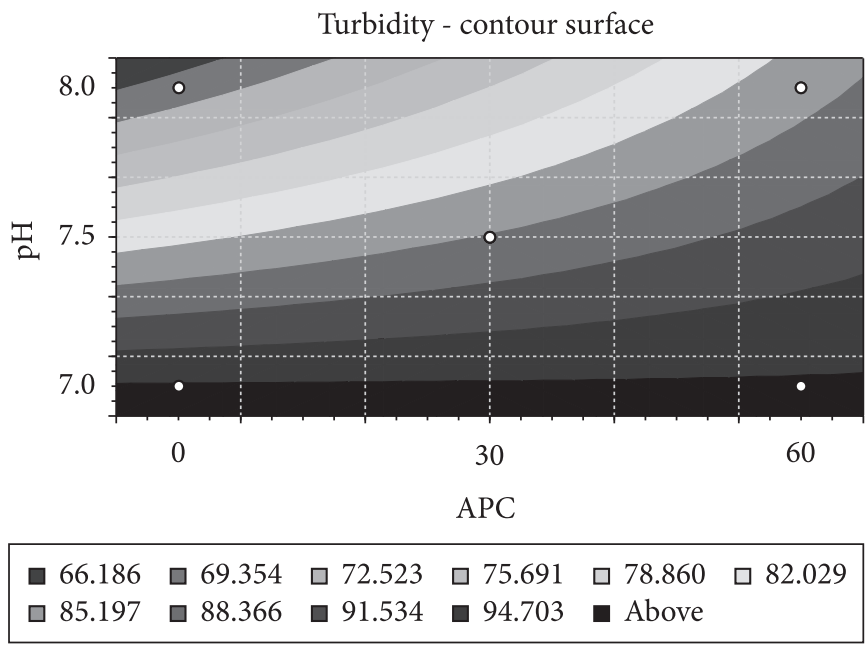

Figure 1. Response surface of the factors APC and $\mathrm{pH}$ for turbidity.

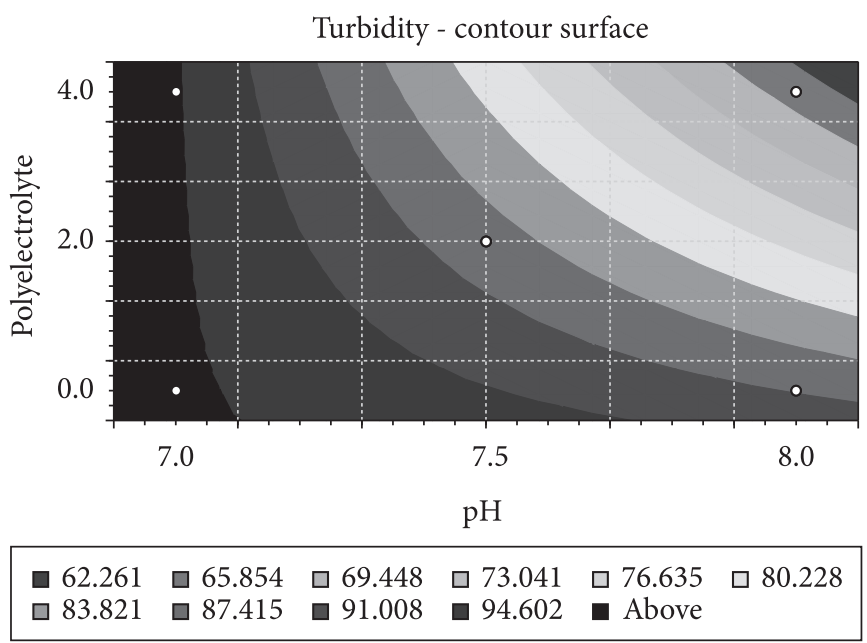

Figure 2. Response surface of the factors $\mathrm{pH}$ and polyelectrolyte for turbidity. 
Eliminating the non-significant factors and applying the $F$ test of the analysis of variance (ANOVA), the significance of the regression and the lack of adjustment at $p \leq 0.25$ were verified. The adjusted model was considered predictive since it presented a significant regression at a level of confidence of $75 \%$ $\left(\mathrm{F}_{\text {calc.regression }}=22,18>\mathrm{F}_{\text {tab:0.25:2:8 }}=1.66\right)$, a non-significant lack of adjustment at the same level $\left(\mathrm{F}_{\text {calc.lack adjust }}=0.61<\mathrm{F}_{\text {tab;0.25;6; }}=1.65\right)$, and a regression coefficient $\left(\mathrm{R}^{2}=0.90\right)$ greater than 0.85 .

Figure 3 shows the effect of the interaction between APC and polyelectrolyte on the response score for the attribute turbidity; a graph similar to this one was drawn based on the interaction between $\mathrm{pH}$ and the polyelectrolyte.

Figure 3 shows that the turbidity's lowest values occurred at high levels of APC and polyelectrolyte concomitantly. Agraph similar to this one was drawn based on the interaction between $\mathrm{pH}$ and the polyelectrolyte, elucidate thus that the lowest turbidity's values occurred in high levels of $\mathrm{pH}$ and polyelectrolyte concomitantly. These results according to the instrumental analysis of turbidity (Figure 2), i.e., the highest values of $\mathrm{pH}$, polyelectrolyte, and APC promotes major flocculation and thus reduces the sugar cane juice's turbidity.

Analyzing the effects and regression coefficients of the factors APC, $\mathrm{pH}$, and polyelectrolyte (linear regression and the interactions between them) for the attribute of global appearance, it was possible to conclude that all the factors showed significant effects on the response at a level of $75 \%$ of significance (Table 7).

Table 5. Means of the scores awarded to the treatments (assays) for the attributes of color, turbidity, and overall appearance.

\begin{tabular}{cccc}
\hline Assays & Color & Turbidity & Appearance \\
\hline 1 & 6,22 & 6,09 & 5,91 \\
2 & 6,31 & 6,30 & 5,99 \\
3 & 6,10 & 6,26 & 6,27 \\
4 & 6,97 & 6,51 & 6,61 \\
5 & 6,42 & 6,52 & 6,18 \\
6 & 6,15 & 6,17 & 5,79 \\
7 & 5,87 & 6,21 & 6,00 \\
8 & 6,24 & 6,06 & 5,74 \\
9 & 6,16 & 6,23 & 5,95 \\
10 & 6,14 & 6,17 & 5,92 \\
11 & 6,11 & 6,36 & 5,99 \\
\hline
\end{tabular}

Table 6. Estimated effect, statistical significance, and regression coefficient of the factors for the attribute of turbidity $\left(\mathrm{R}^{2}=0,90\right)$.

\begin{tabular}{lccc}
\hline \multicolumn{1}{c}{ Factors } & $\begin{array}{c}\text { Estimated } \\
\text { effect }\end{array}$ & $\begin{array}{c}\text { Statistical } \\
\text { significance }(\mathrm{p})\end{array}$ & $\begin{array}{c}\text { Regression } \\
\text { coefficient }\end{array}$ \\
\hline General mean & 6,261818 & $2,19 \mathrm{E}-05$ & 6,261818 \\
$(1)$ APC & $-0,01$ & 0,897582 & $-0,005$ \\
$(2)$ pH & $-0,01$ & 0,897582 & $-0,005$ \\
$(3)$ polyelectrolyte & $-0,05$ & 0,542291 & $-0,025$ \\
$1 * 2$ & 0,06 & 0,474439 & 0,03 \\
$1 * 3$ & $-0,24$ & 0,07303 & $-0,12$ \\
$2 * 3$ & $-0,2$ & 0,100461 & $-0,1$ \\
\hline
\end{tabular}

Applying the $\mathrm{F}$ test of the analysis of variance (ANOVA), the significance of the regression and the lack of adjustment at $\mathrm{p} \leq$ 0.25 were verified. The adjusted model was considered predictive since it presented a significant regression at a level of confidence of $75 \%\left(\mathrm{~F}_{\text {calc.regression }}=12.56>\mathrm{F}_{\text {tab:0.25:6.4 }}=2.08\right)$, a non-significant lack of adjustment at the same level $\left(\mathrm{F}_{\text {calc.lack adjust }}=1.83<\mathrm{F}_{\text {tab; } 0.252 .24}=2,00\right)$, and a regression coefficient $\left(\mathrm{R}^{2}=0,95\right)$ greater than 0.85 .

Figures 4, 5, and 6 show the significant interactions with respect to the response score for the attribute appearance.

In Figure 4, the best scores for the attribute appearance are observed at high values of $\mathrm{pH}$ because this factor promotes major flocculation and minor turbidity of the sugar cane juice. On the other hand, Figure 5 explains the little effect of the levels of polyelectrolyte on the appearance and major scores of this attribute at high values of APC showing their major effect on the appearance. Figure 6, as well as Figure 4, shows high scores of appearance in high values of $\mathrm{pH}$ and explains the little effect of the polyelectrolyte on this attribute, as well as showed by Figure 5.

Analyzing the effects and the coefficients of regression of the factors APC, $\mathrm{pH}$, and polyelectrolyte (linear regression and the interactions between them) for the attribute color, it was concluded that only $\mathrm{pH}$ failed to have a significant effect on the response at the $75 \%$ level of significance (Table 8 ).

Table 7. Estimated effect, statistical significance, and regression coefficient of the factors for the attribute of appearance $\left(R^{2}=0,95\right)$.

\begin{tabular}{lccc}
\hline \multicolumn{1}{c}{ Factors } & $\begin{array}{c}\text { Estimated } \\
\text { effect }\end{array}$ & $\begin{array}{c}\text { Statistical } \\
\text { significance }(\mathrm{p})\end{array}$ & $\begin{array}{c}\text { Regression } \\
\text { coefficient }\end{array}$ \\
\hline General mean & 6,031818 & $3,08 \mathrm{E}-06$ & 6,031818 \\
(1) APC & $-0,0575$ & 0,146586 & $-0,02875$ \\
$(2) \mathrm{pH}$ & 0,1875 & 0,017092 & 0,09375 \\
$(3)$ polyelectrolyte & $-0,2675$ & 0,008508 & $-0,13375$ \\
$1^{\star 2}$ & 0,0975 & 0,059171 & 0,04875 \\
$1^{\star 3}$ & $-0,2675$ & 0,008508 & $-0,13375$ \\
$2^{* 3}$ & $-0,3025$ & 0,006672 & $-0,15125$ \\
\hline
\end{tabular}

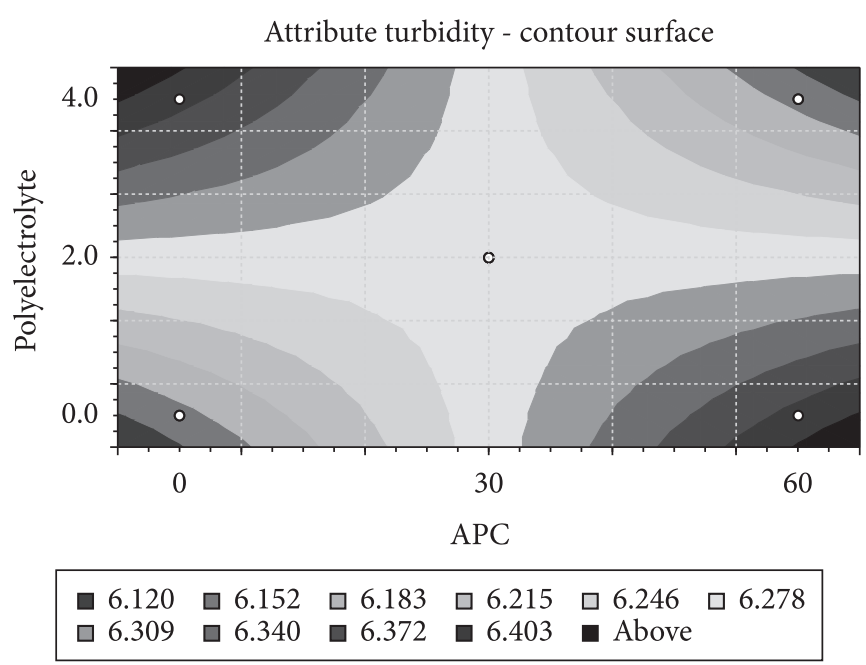

Figure 3. Response surface of the factors APC and polyelectrolyte for the attribute of turbidity. 


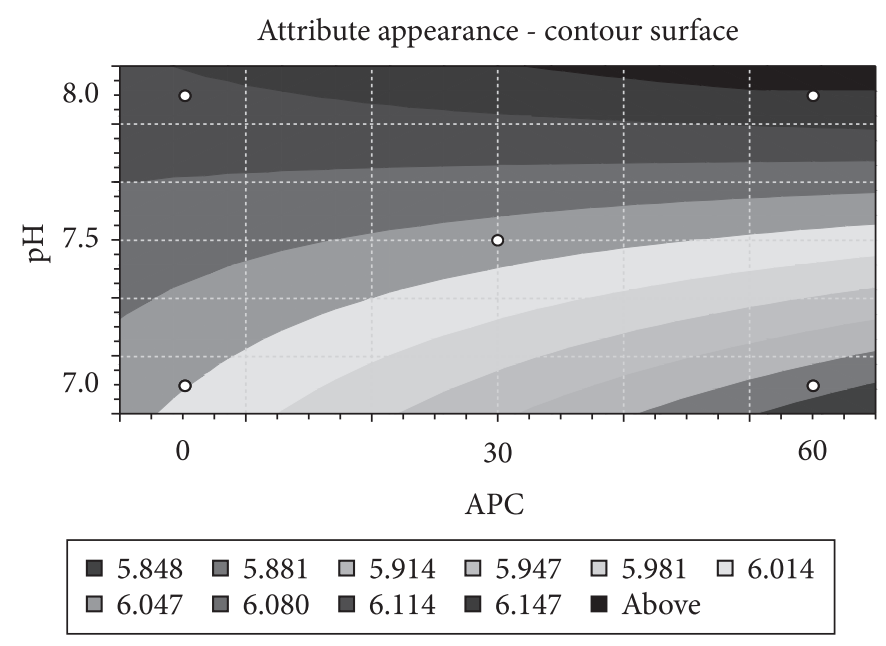

Figure 4. Response surface of the factors APC and $\mathrm{pH}$ for the attribute appearance.

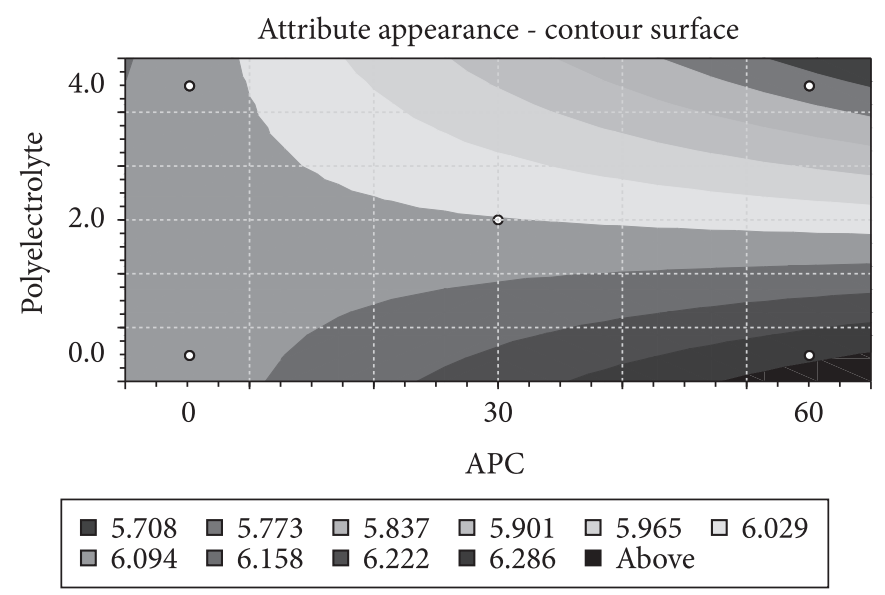

Figure 5. Response surface of the factors APC and polyelectrolyte for the attribute appearance.

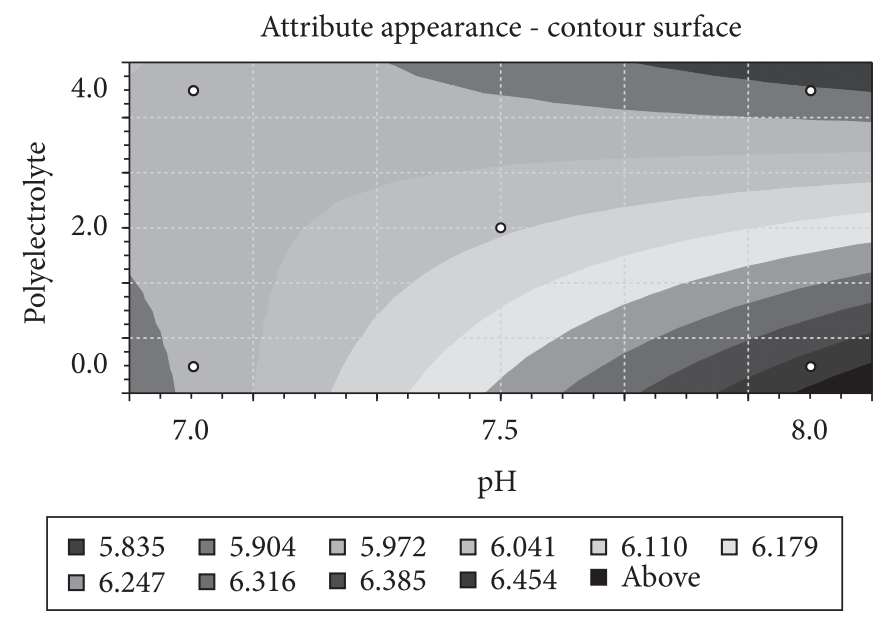

Figure 6. Response surface of the factors $\mathrm{pH}$ and polyelectrolyte for the attribute appearance.
Eliminating the non-significant factor and applying the $F$ test of the analysis of variance (ANOVA), the significance of the regression and the lack of adjustment at $\mathrm{p} \leq 0.25$ were verified. The adjusted model was considered predictive since it presented a significant regression at a level of confidence of 75\% $\left(\mathrm{F}_{\text {calc.regression }}=13.64>\mathrm{F}_{\text {tabi:0.25.5.5 }}=1.89\right)$, a non-significant lack of adjustment at the same level ( $\left.\mathrm{F}_{\text {calc.lack adjust }}=1.63<\mathrm{F}_{\text {tab; } 0.25 ; 3.5}=1.88\right)$, and a regression coefficient $\left(\mathrm{R}^{2}=0.93\right)$ greater than 0.85 .

Figures 7, 8, and 9 show the significant interactions with respect to the response score for the attribute color.

For the attribute color (Figure 7), higher scores were obtained at high levels of $\mathrm{pH}$ and APC concomitantly because these values promote best turbidity and appearance of the sugar cane juice. Figure 8 shows the little effect of the polyelectrolyte in the attribute color and higher scores for this sensorial parameter at high level of APC because this factor improves the turbidity and the appearance of the beverage. Figure 9 illustrates high scores for the attribute color at high levels of $\mathrm{pH}$, as well as the small effect of the polyelectrolyte on this sensorial parameter, in accordance with Figure 8.

The choice of the best clarification treatment for sugar cane juice for human consumption was made considering the following results:

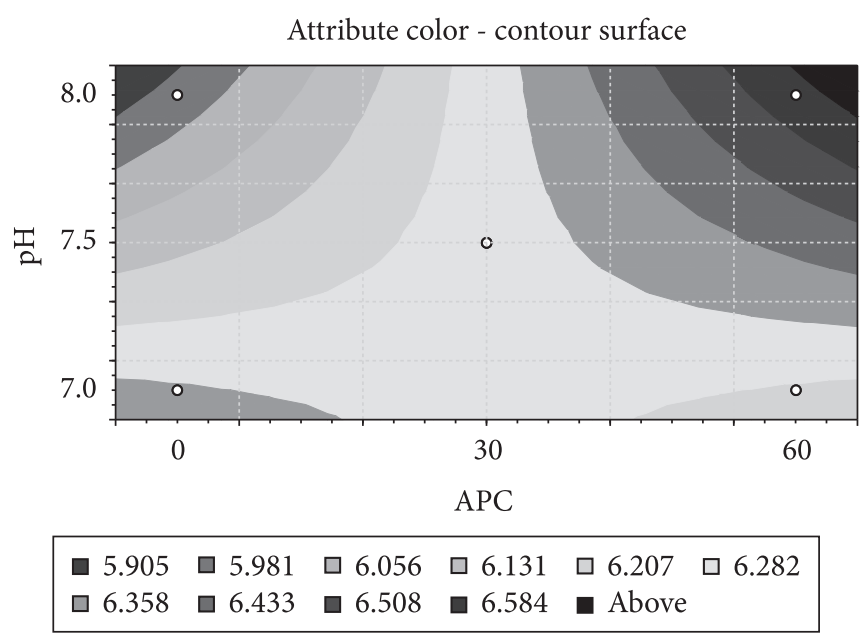

Figure 7. Response surface of the factors APC and $\mathrm{pH}$ for the attribute color.

Table 8. Estimated effect, statistical significance, and regression coefficient of the factors for the attribute color $\left(R^{2}=0,93\right)$.

\begin{tabular}{lccc}
\hline \multicolumn{1}{c}{ Factors } & $\begin{array}{c}\text { Estimated } \\
\text { effect }\end{array}$ & $\begin{array}{c}\text { Statistical } \\
\text { significance (p) }\end{array}$ & $\begin{array}{c}\text { Regression } \\
\text { coefficient }\end{array}$ \\
\hline General mean & 6,244545 & $1,48 \mathrm{E}-06$ & 6,244545 \\
(1) APC & 0,265 & 0,004479 & 0,1325 \\
$(2)$ pH & 0,02 & 0,377829 & 0,01 \\
$(3)$ polyelectrolyte & $-0,23$ & 0,005933 & $-0,115$ \\
$1^{\star 2}$ & 0,355 & 0,002503 & 0,1775 \\
$1^{\star 3}$ & $-0,215$ & 0,006781 & $-0,1075$ \\
$2 * 3$ & $-0,25$ & 0,005028 & $-0,125$ \\
\hline
\end{tabular}


- For the attribute Turbidity, the best scores were obtained when $\mathrm{APC}=60 \mathrm{ppm} / \mathrm{pH}=8 /$ polyelectrolyte $=0$ or $\mathrm{APC}=$ $0 \mathrm{ppm} / \mathrm{pH}=7 /$ polyelectrolyte $=4 \mathrm{ppm}$ (Figure 3 );

- For the attribute appearance, the highest scores were awarded to the treatment APC $=60 \mathrm{ppm} / \mathrm{pH}=8 /$ polyelectrolyte $=0 \mathrm{ppm}$ (Figures 4, 5 and 6);

- For the attribute Color, the best scores were obtained when $\mathrm{APC}=60 \mathrm{ppm} / \mathrm{pH}=8 /$ polyelectrolyte $=0 \mathrm{ppm}$ (Figures 7 , 8 and 9); and

- Considering good turbidity for sugar cane juice as being approximately equal to $90 \%$ (chosen as a result of a previous sensory analysis), the value found for APC was $\mathrm{APC}=60 \mathrm{ppm} / \mathrm{pH}=8 /$ polyelectrolyte $=0 \mathrm{ppm}$.

Therefore, the best treatment to obtain a low level of polysaccharides, turbidity of about $90 \%$, and high scores for the attributes of color, appearance, and turbidity, was treatment 4 $(\mathrm{APC}=60 \mathrm{ppm} / \mathrm{pH}=8 /$ polyelectrolyte $=0 \mathrm{ppm})$.

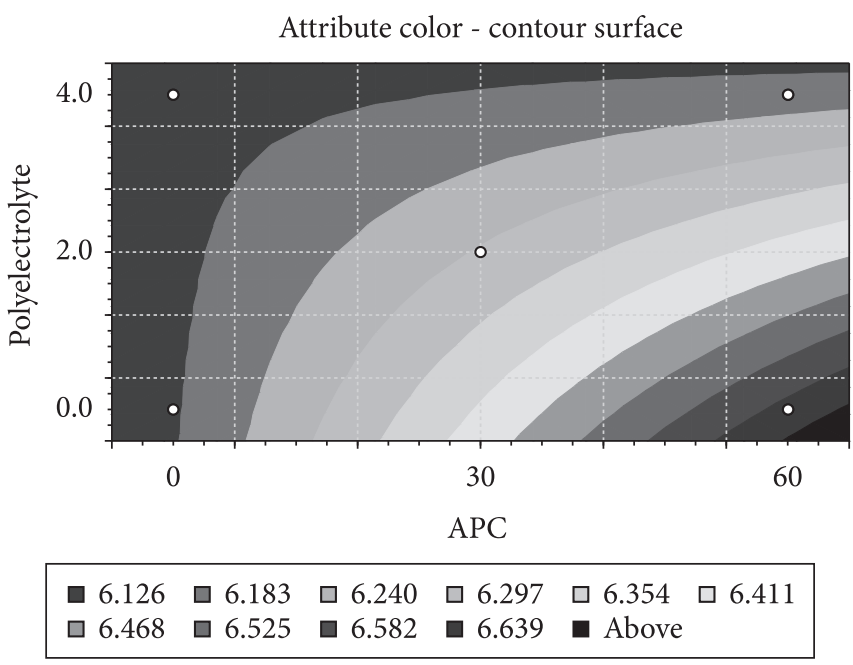

Figure 8. Response surface of the factors APC and polyelectrolyte for the attribute color.

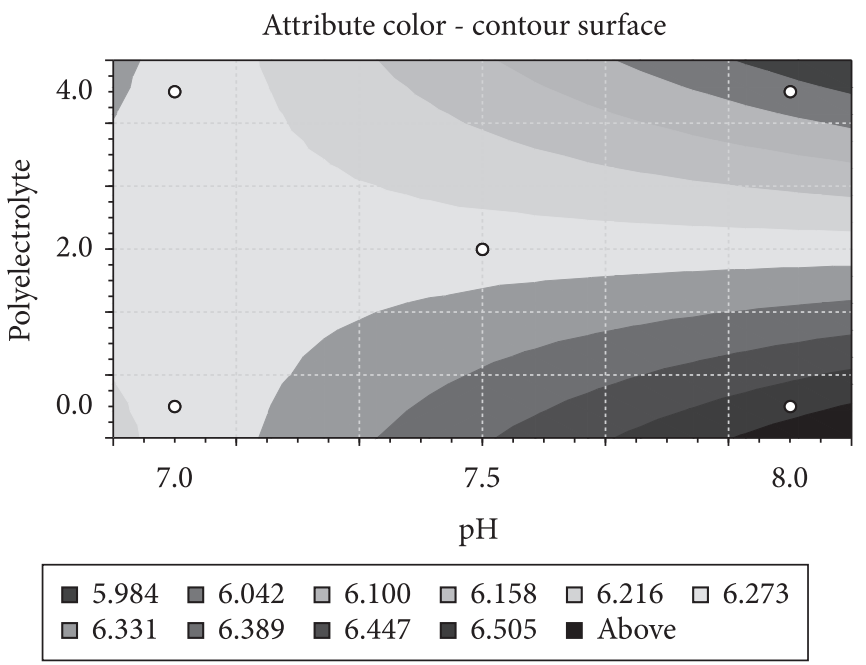

Figure 9. Response surface of the factors $\mathrm{pH}$ and polyelectrolyte for the attribute color.
In the acceptance test, the treatment 4 shows average scores of 5.91 for flavor, 5.39 for taste, and 5.60 for global impression (Table 9). In the test of purchase's intention (Figure 10), $49 \%$ of the responses responded between 4 ("possible would buy") and 5 ("certainly would buy") thus illustrating a good acceptance of the beverage by the consumers.

\subsection{Other determinations}

The results for color determination for each treatment can be seen in Table 10 .

When the values of $\mathrm{L}$ - parameter are positive, the sample is light, and if the values are negative, it is dark. With respect to the values of a - parameter, when the values are positive, the sample tends to red color; and if the values are negative, it tends to become green color. For the $\mathrm{b}$ - parameter, the positive values indicated yellow color and the negative, blue.

Except for samples 7 and 8, it can be seen that all other samples were of practically the same yellow tone. With respect to luminosity, all samples were light and very similar to each other -7 being the lightest and 2 the darkest.

Figure 11 shows the differences found for each sample if compared to the standard -sample 12 ("in nature" cane juice) in terms of $\mathrm{L}, \mathrm{a}$, and $\mathrm{b}$ - parameters.

From Figure 11, it is possible to confirm the data in Table 9, i.e., $\mathrm{t}$ samples 1,2 , and 11 are a little darker than the standard (sample 12), and 7 and 8 considerably lighter; these last two samplers are considerably less red than the standard, and samples 1, 2, 5, 6, and 11 were moderately redder. The majority of the samples were slightly more yellow than the standard, but samples 7 and 8 were much less yellow. In conclusion, samples 7 and 8 were the most different from the standard in terms of color and luminosity.

Table 9. Means of the chose treatment's sensorial test for flavor, taste, and global impression attributes.

\begin{tabular}{lc}
\hline Attributes & Means \\
\hline Flavor & 5,91 \\
Taste & 5,39 \\
Global impression & 5,60 \\
\hline
\end{tabular}

Table 10. Results for the decantation process speed and color analysis (L-luminosity; a-intensity from red to green; and b-intensity from yellow to blue).

\begin{tabular}{cccc}
\hline Treatment (assay) & L - parameter & a - parameter & b - parameter \\
\hline 1 & 62,03 & 7,38 & 42,73 \\
2 & 61,81 & 7,51 & 42,71 \\
3 & 81,00 & 2,62 & 35,89 \\
4 & 71,77 & 4,95 & 39,45 \\
5 & 67,85 & 7,08 & 41,65 \\
6 & 67,77 & 6,96 & 41,43 \\
7 & 89,80 & $-0,17$ & 22,57 \\
8 & 89,00 & $-1,37$ & 21,05 \\
9 & 67,95 & 5,63 & 42,65 \\
10 & 68,55 & 5,62 & 42,72 \\
11 & 66,72 & 6,80 & 42,40 \\
12 (natural) & 67,80 & 4,75 & 41,04 \\
\hline
\end{tabular}




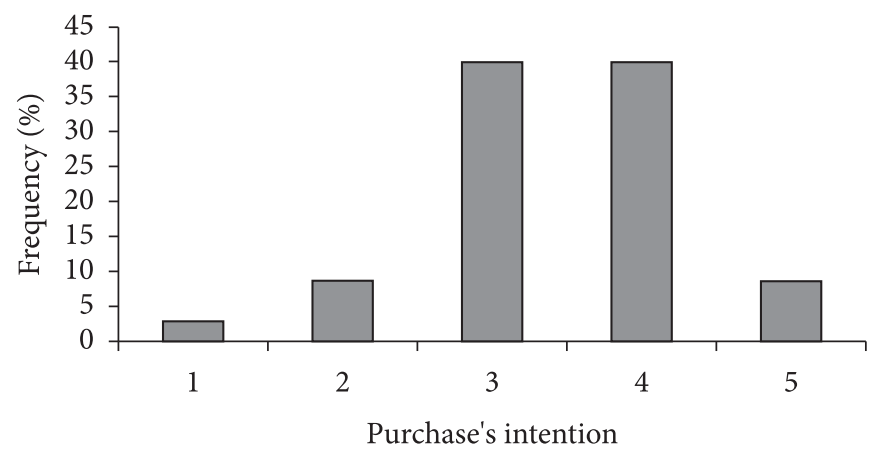

Figure 10. Test of purchase's intention (1-certainly wouldn't buy; 2-possible wouldn't buy; 3-maybe would buy/maybe wouldn't buy; 4-possible would buy; 5-certainly would buy).

Trend plot (CIELAB 10\% 1 65)

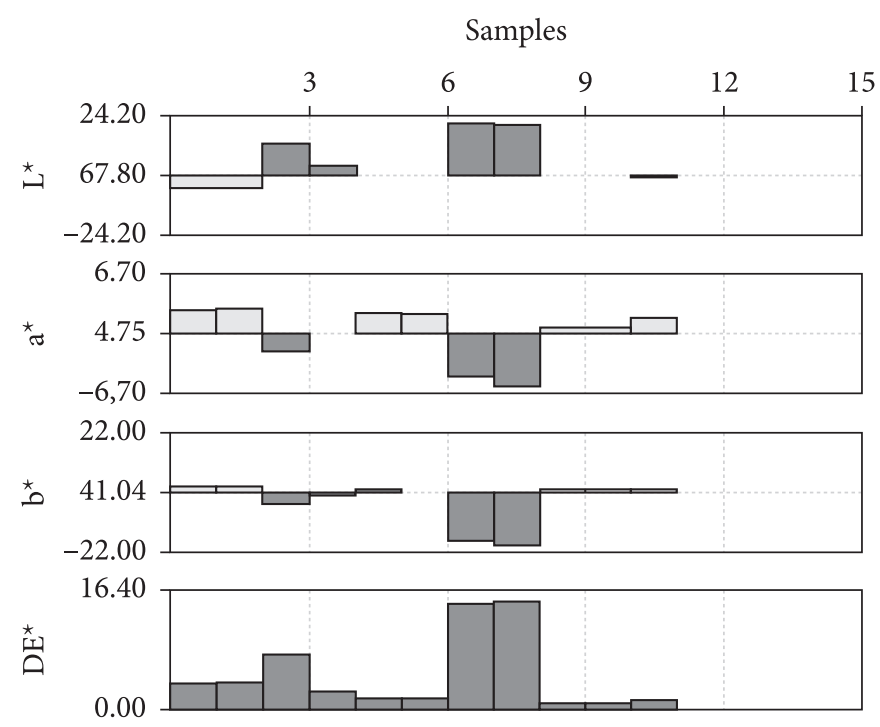

Illuminant/observator $=\mathrm{D} 65 / 10^{\circ}$

Lab. Instrumentação - DTA/UNICAMP

StdzMode: TTAN

Figure 11. Difference with respect to the standard in terms of L, a, and $\mathrm{b}$ - parameters.

\section{Conclusions}

Considering the results obtained, treatment $4(\mathrm{APC}=60 \mathrm{ppm} /$ $\mathrm{pH}=8 /$ polyelectrolyte $=0 \mathrm{ppm})$ was defined the as the most adequate for the clarification of sugar cane juice for the consumption.

\section{Acknowledgements}

The authors are grateful for the scientific, technical, and financial support provided by The National Council for Scientific and Technological Development (CNPq) and by FAPESP (The State of São Paulo Research Foundation).

\section{References}

BARROS NETO, B.; SCARMINIO, I. S.; BRUNS, R. E. Planejamento e otimização de experimentos. 2. ed. Campinas: UNICAMP, 1995.

COPERSUCAR. Clarificação. São Paulo: Centro de Tecnologia Copersucar, 1994.

DELGADO, A. A. A clarificação do caldo de canas despalhadas manualmente e a fogo, em função do tempo de espera para a industrialização. 1975. 148 f. Tese (Livre Docência) - Escola Superior de Agricultura Luiz de Queiroz, Universidade de São Paulo - USP, Piracicaba, 1975.

DELGADO, A. A.; CESAR, M. A. A. Elementos de tecnologia e engenharia do açúcar de cana. Piracicaba: Escola Superior de Agricultura "Luiz de Queiroz", Universidade de São Paulo - USP, 1989. v. 2.

DREYWOOD, R. Qualitative test for carbohydrate material. Industry and Engineering Chemistry Analytical, v. 18, p. 499, 1946.

IADEROZA, M.; DRAETTA, I. S. Ênzimos e Pigmentos - influências e alterações durante o processamento. In: SOLER, M. P. et al. Industrialização de frutas. 2. ed. Campinas: Instituto de Tecnologia de Alimentos, 1991. cap. 2, p. 17-31. (Manual Técnico, 8).

KOBLITZ, M. G. B. Estudo de método para remoção de polissacarídeos que precipitam em cachaça. 1998. 85 f. Dissertação (Mestrado)Faculdade de Engenharia de Alimentos, Universidade Estadual de Campinas, Campinas, 1998.

KOBLITZ, M. G. B.; MORETTI, R. H. Polysaccharide removal from refined sugar syrup. Internacional Sugar Journal, v. 101, n. 1206, p. 323-325, 1999.

LEME JUNIOR, J.; BORGES, J. M. Açúcar de cana. Viçosa: Imprensa Universitária, 1965.

MEILGAARD, M.; CIVILLE, G. V.; CARR, B. T. Sensory Evaluation Techniques. New York: CRC Press, 1987. 281 p.

PAYNE, J. H. Operações unitárias na produção de açúcar de cana. São Paulo: Nobel, 1989.

ROBERTS, E. J. Dextran analysis in sugar process liquors and juices: a comparative study of methods. In: CONFERENCE ON SUGAR PROCESSING RESEARCH. Proceedings... 1982, p. 298-307.

SOUZA, J. Estudo da eficiência de alguns polieletrólitos utilizados na clarificação do caldo de cana. 1988. 101 f. Dissertação (Mestrado)Escola Superior de Agricultura Luiz de Queiroz, Universidade de São Paulo, Piracicaba, 1988.

STONE, H.; SIDEL, J. L. Sensory evaluation practices. New York: Academic Press, 1993.

STUPIELLO, J. P. Cana-de-açúcar: cultivo e utilização. Campinas: Fundação Cargil, 1987. p. 761-804. (A cana-de-açúcar como matéria-prima, v. 2). 